\title{
Den Europæiske union under forandring
}

Af Hans Kundnani 
Tyskland får mere magt i EU, og de ændringer det medfører, kan ændre opfattelsen af selve EU, så at det der engang blev set som et middel til at udligne forskelle, nu i stigende grad risikerer at blive set som et middel til 'blød dominans'

I en forelæsning i Oxford i oktober 2012 sagde den tyske finansminister Wolfgang Schäuble "krisen langt fra har spoleret det europæiske projekt, den har tværtimod fremskyndet det”, og på en måde har han selvfølgelig ret. Krisen har været katalysator for en fremskyndet integrationsproces, som ville have være utænkelig under andre omstændigheder. Medlemsstater har taget skridt, som under andre omstændigheder ville have været utænkelige, til at overføre magt til det europæiske niveau især - men ikke kun - over deres økonomier. Selv om de europæiske ledere har afstået fra at implementere de fire 'byggesten' mod en 'ægte økonomisk og monetær union' som foreslået af formanden for Det Europæiske Råd Herman van Rompuy i sommeren 2012, så har de skabt en bankunion.

Men selv om man kan argumentere for, at der er sket fremskridt i europæisk integration, så rejser de skridt, der er blevet taget som svar på krisen, grundlæggende spørgsmål om det europæiske projekts fremtid. Selv om integrationen fortsætter og endda fremskyndes, så ændrer den måske Den Europæiske Union på en ganske problematisk måde, samtidig med at den åbner for nye skillelinjer mellem medlemsstaterne, som vil have betydelige og måske negative konsekvenser for sammenhængskraften i EU. Påstanden om, at krisen har "bidraget til at fremme" det europæiske projekt skal derfor undersøges nærmere.

I det følgende vil jeg undersøge fire problematiske måder, hvorpå EU har ændret sig, siden krisen begyndte. For det første kan der opstå et EU, der gør mere brug af tvang over for medlemsstaterne. Dernæst er der inden for eurozonen opstået et skel mellem overskuds- og underskudslande, og der er opstået et ny kerne, som ikke har meget at gøre med villigheden til at overføre suverænitet til EU-niveau. For det tredje har krisen tvunget Tyskland ind i en magtposition, der er uden fortilfælde, og som er ved at ændre opfattelse af EU. Endelig har den yderligere integration, der har fundet sted siden krisen begyndte, skabt et Europa i tre lag, bestående af eurozonen, 'pre-ins' såsom Polen og 'opt-outs' som Storbritannien.

EU er et enestående fænomen i international politik: Et regionalt integrationsprojekt, der er blevet 'mere end en mellemstatslig organisation men mindre end en fuldt udviklet europæisk stat' (se Christopher Hill/Michael E. Smith (eds.), International Relations and the European Union (Oxford: Oxford University Press, 2005), side 4). Frem for alt var den integration, der begyndte med Schuman-planen i 1950 baseret på frivillig snarere end tvungen overførsel af suverænitet. EU var derfor, efterhånden som den udviklede sig, i stand til at fungere som en form for civiliseret struktur, som accepterede og håndterede forskelle i Europa, samtidig med at den skabte konvergens baseret mere på kompromis end på tvang. Det lægger 'meget snævrere grænser for de taktiske manøvrer, som medlemsstaterne er parate til at bruge mod hinanden, end det er tilfældet mellem ethvert tilfældigt parrede sæt af

Hans Kundnani er reseach director ved European Council on foreign relations, Han beskæftiger sig indgående med Tyskland og tysk EU-politik. Han har tidligere arbejdet som korrespondent i Berlin for The Observer 
stater i international politik' (se op. cit. side 8). Først og fremmest udelukkede den militær magt som et legitimt middel til at løse uoverensstemmelser inden for Europa.

For at løse den aktuelle krise synes EU imidlertid at udvikle sig i en ny - og når man tager dens aspirationer i betragtning - problematisk retning. For det første er skridtene mod yderligere integration, siden krisen begyndte, taget på grundlag af en blanding mellem frivillig og tvungen overførsel af suverænitet. Teknisk følger de selvfølgelig mange af de samme procedurer som tidligere integrative skridt; ingen er blevet tvunget til at acceptere yderligere integration. Men virkeligheden er, at eurozonelandene ikke rigtig har haft andre valg end at overføre magt til det europæiske niveau. Som europæiske ledere som Angela Merkel gang på gang har fortalt dem, er der ikke noget alternativ. På den måde har det været 'integration med en pistol for panden'.

For det andet, for at rette fejlene i den monetære unions opbygning indfører EU nu er meget strengere system af regler og håndhævelse af regler. Selv om krisen på dramatisk vis har afsløret Maastricht-regimets manglende evne til at skabe konvergens i det fælles valutaområde, så har eurozonelandene med Tyskland i spidsen søgt at udvide og stramme det regelsystem, som Maastricht har skabt, såvel som håndhævelsen af det. Det 'Maastricht III'-system, der er udsprunget af krisen, og som er baseret på en serie af forholdsregler taget siden krisen, som kulminerede i finanspagten, griber mere ind og pålægger strengere økonomisk-politiske betingelser og større homogenitet end dets to forgængere. Man kan nu høre tyske politikere og embedsmænd citere Lenin: “Tillid er godt, kontrol er bedre." Den måde systemet fungerer på, ses selvfølgelig i sin mest ekstreme form i eurozonens kriselande. Det ser således ud til, at der af krisen er opstået et EU, hvor tvang spiller en større rolle end tidligere.

Det skaber spændinger mellem med- lemslande (mellem overskudslande og underskudslande) og inden for landene (mellem elite og befolkning). Dette sker igen i sin mest ekstreme form i kriselandene. Dette mere tvangsmæssige EU synes at være milevidt fra grundlæggernes visioner. Morgenen efter at man var enedes om finanspagten på det europæiske topmøde i december 2011 skrev Ian Traynor i The Guardian, at der ud af eurokrisen var kommet en glædesløs union af bøder, afstraffelse, opdragelse og sydende vrede.

\section{Ny 'kerne' og 'periferi'}

I 1994 - da der stadig kun var 12 lande i EU - udviklede Wolfgang Schäuble og hans kristendemokratiske kollega Karl Lamers ideen om et 'Kerneeuropa'. De argumenterede for, at de medlemsstater, der ønskede det, skulle gå videre i integrationsprocessen, selv om ikke alle var villige til det. Medlemsstater som fx Danmark og Storbritannien, der havde 'opt-outs' på forskellige områder ville komme til at stå uden for denne kerne. Det ville skabe et Europa i flere hastigheder, men Schäuble og Lamers håbede, at 'kernen' ville fungere som en magnet, og at andre lande efterhånden ville følge efter. Medlemskabet af Kerneeuropa ville således alene blive defineret af villigheden til at integrere.

Imidlertid er der siden eurokrisen startede opstået en anden slags 'kerne'. Begrebet bruges nu i almindelighed ikke om de lande, der er rede til at gå længst med hensyn til integration, men snarere om eurozonens kreditorlande, som omfatter Finland, Tyskland og Holland. Der er med andre ord en ny 'kerne' i 'kernen'. Samtidig omtales underskudslandene nu almindeligvis som 'periferien' - et begreb, der inden krisen begyndte, i EU-sammenhæng kun blev brugt om lande, der geografisk lå i periferien.

Den mest slående illustration af denne nye terminologi er den måde, hvorpå Italien - et af de oprindelige seks lande, der grundlagde EF og, i hvert tilfælde indtil 
krisen begyndte, et af de mest proeuropæiske - nu tilhører 'periferien'

Denne nye brug af begreberne 'kerne' og 'periferi' - der som George Soros har påpeget er et levn fra imperiale forbindelser afspejler det skel mellem kreditor- og debitorlande inden for eurozonen, som er opstået, siden krisen startede. Før krisen startede var den centrale skillelinje i EU mellem vest og øst, eller som den tidligere amerikanske forsvarsminister Donald Rumsfeld udtrykte det, mellem 'det gamle' og 'det ny' Europa. Men siden krisens start er der opstået en ny skillelinje, som ofte beskrives som nord-syd (enkelte debitorlande som fx Irland kan dog næppe beskrives som hørende til syd).

Der er en reel fare for, at denne nye skillelinje bliver permanent. Man har allerede set en betydelig kapitalflugt fra periferien; nu begynder en sand folkevandring af unge mennesker fra debitorlande med høj arbejdsløshed som Grækenland og Spanien til kreditorlande som Tyskland. I første halvdel af 2012 steg indvandringen til Tyskland med omkring 15 pct. til omkring en halv million - de fleste fra andre EU-lande. Indvandringen til Tyskland fra Grækenland, Spanien og andre kriseramte sydlige lande er steget endnu hurtigere. Faren er ifølge Soros, at både menneskelige og finansielle ressourcer vil blive draget mod midten, og at 'periferien' bliver permanent kriseramt. (New York Review of Books (7 September 2012), http://www.nybooks.com/articles/archives/2012/sep/27/ tragedy-european-union-and-how-resolve-it/?pagination=false)

Det er helt forskelligt fra det Europa vi kendte. Men mange proeuropæere synes at have forliget sig med dette delte Europa. Mange argumenterer, at de forskelle i rentesatser mellem overskuds- og underskudslande - det såkaldte rentespænd - afspejler virkeligheden og derfor ikke behøver at blive korrigeret. Der er endda nogle, der hævder, at vandringen fra underskuds- til over- skudslande simpelthen er udtryk for EU's princip om fri bevægelighed - og derfor kan ses som et 'fremskridt' skabt af krisen. Men et Europa med en varig skillelinje mellem 'kerne' og 'periferi' er ikke helt hvad EU's grundlæggere - eller for den sags skyld skaberne af den fælles mønt - havde i tankerne.

En sådan skillelinje vil også være i modstrid med, hvordan Europa opfatter sig selv. EU formodes at være forskellig fra og mere 'social' end USA. Men hvis Europa ikke afhjælper den ubalance, der er skabt af eurozonen, og kapital- og hjerneflugten, frygter Soros, at hele regioner vil være dømt til at blive affolket og være underpriviligeret. Faktisk har nogle økonomer så som Martin Wolf advaret om, at meget af Sydeuropa står over for en fremtid, der svarer til Mississippis. Det ekstraordinære er, at mange proeuropæere, særligt på centrum-højrefløjen, på kort tid har forliget sig med tanken.

\section{Et tysk Europa}

I midten af den ny 'kerne' finder vi selvfølgelig Tyskland. EU blev til dels skabt for at begrænse Tysklands magt - faktisk var dette måske den stærkeste enkeltkraft bag europæisk integration. Men aldrig i EU's historie har en enkelt medlemsstat relativt været så stærk som Tyskland er nu. Siden krisen begyndte, har der været megen debat om et muligt tysk overherredømme i Europa, og også om den mulige opståe af et tysk 'imperium - historiske fænomener, som det var meningen at EU skulle udrydde (se fx See Hans Kundnani, "What hegemon?", in: IP Journal, 4 May 2012, https://ip-journal. dgap.org/en/ip-journal/topics/what-hegemon; idem, "A German empire?", in: Project Syndicate, 21 June 2012, http://www.project-syndicate.org/blog/a-german-empire.)

Thomas Manns berømte ord fra 1953 opfodrede til et 'europæisk Tyskland' frem for et 'tysk Europa', men siden krisen begyndte, er det blevet almindeligt at tale om, at et tysk Europa som resultat heraf.

Tidligere var EU's fransk-tyske lederskab 
baseret på det, Stanley Foffmann kaldte 'uligevægtenes ligevægt' mellem et Frankrig, der blev set som ledende på det politiske område, og et Vesttyskland, der var stærkere på det økonomiske felt: Frankrig var således EU's førende politiske magt, og Vesttyskland var den førende økonomiske magt. I løbet af det seneste årti er Tyskland imidlertid blevet mere direkte med hensyn til at forfølge sin nationale interesse i Unionen, og Frankrig har mistet sin konkurrencedygtigtighed i forhold til Tyskland. Balancen mellem de to lande er blevet forstyrret. Derfor er den måde, hvorpå de to lande indgår aftaler, ændret. Tyskland er nu i stand til at diktere vilkårene til Frankrig og andre lande på en måde, det ikke kunne tidligere.

På baggrund af denne enestående magt har Tyskland de seneste tre år søgt at eksportere sin økonomiske model, som Tyskland, rigtigt eller forkert, ser som den eneste måde at løse krisen på og gøre Europa konkurrencedygtigt (og derfor som tjenende den europæiske interesse snarere end blot den nationale tyske). Eurozonelandene har indført strukturelle reformer baseret på dem, som Gerhard Schröder introducerede i Tyskland, og de har accepteret at indføre en version af den 'gældsbremse', som Tyskland introducerede i 2009. Tyskland har dog ikke altid fået sin vilje, siden krisen begyndte, men det har kun givet indrømmelser, når det er blevet tvunget til det af en koalition af andre eurozonelande eller af det finansielle marked.

Konsekvensen af forøgelsen af Tysklands magt er, at de strengere økonomiske og politiske betingelser, som nu er blevet pålagt for at gøre underskudslande som Grækenland og Italien mere konkurrencedygtige, ses som hidrørende fra Berlin snarere end Bruxelles. I praksis kan denne hidtil usete sætten lighedstegn mellem EU og Tyskland gøre det vanskeligere at pålægge økonomiske og politiske betingelser, og det kan øge modstanden mod dem. Det mest dramatiske eksempel herpå er de antityske stem- ninger i Grækenland siden krisen. Men den kan også ændre opfattelsen af selve EU: Det, der engang blev set som et middel til at overkomme forskelle, kan i stigende grad blive set som et middel for det, som Kalypso Nicolaïdis har kaldt 'blød dominans'.

\section{Europa i tre lag}

Samtidig med, at en ny kløft er åbnet inden for eurozonen, og magten i stigende grad er blevet centreret omkring Tyskland, er der også blevet større afstand mellem eurozonen og landene uden for eurozonen. Det er korrekt, som proeuropæere ofte påpeger, at to lande (Estland og Letland) har tilsluttet sig den fælles valuta, siden krisen begyndte. Men de tiltag i retning af yderligere integration, som eurozonen er enedes om, siden krisen begyndte, har hævet tærsklen for lande, som ønsker at tislutte sig den fælles valuta. Selv om man kan argumentere for, at eurozone-'kernen' trods krisen har fungeret som en magnet, således som Schäuble og Lamers håbede på, så er kernen samtidig blevet hårdere.

Den øgede kløft mellem eurozonen og dem, der står udenfor, ses tydeligst i Storbritanniens tilfælde. Selv om Storbritannien forhandlede en 'opt-out' fra ØMU'en i forbindelse med Maastricht-traktaten, har det altid opretholdt en konstruktiv flertydighed med hensyn til, om det på et eller andet tidspunkt ville tilslutte sig euroen. Det har imidlertid ændret sig med krisen, som effektivt har sat en stopper for muligheden for, at Storbritannien ville tilslutte sig den fælles valuta.

Krisen faldt også sammen med David Camerons valg til premierminister i spidsen for en koalitionsregering, i hvilken han presses hårdt af euroskeptikerne. I januar 2013 forkastede Cameron udtrykkeligt ideen om en 'stadig tættere union og forpligtede sig til at holde en folkeafstemning om ja eller nej til britisk medlemskab af EU, hvis han igen bliver premierminister efter valget i 2015 . 
Således er der af krisen opstået et Europa i tre lag. Første lag er eurozonen, der som reaktion på krisen har integreret yderligere og dermed hævet bommen for lande, som ønsker at tilslutte sig den fælles valuta. Andet lag består af de EU-lande, der måske engang i fremtiden vil tilslutte sig den fælles valuta. Men nu er der også for første gang et tredje lag, der består af de lande, som aldrig vil tilslutte sig den fælles valuta. Det står ikke klart, om dette tredje lag er midlertidigt eller permanent. Når alt kommer til alt er det kun Storbritannien, som klart hører til der, og det beslutter måske helt at forlade EU i løbet af de næste få år. Meget afhænger af landene, der i øjeblikket er i det andet lag.

Det er ikke så ligetil helt præcist at definere det andet lag. Mest indlysende er at definere det på basis af forpligtelsen til at tilslutte sig den fælles valuta. I så fald vil laget omfatte alle ikke-eurolande bortset fra Danmark, der befinder sig i det tredje lag sammen med Storbritannien. Man kan imidlertid også definere det andet lag på basis af finanspagten (så er kun Tjekkiet og Storbritannien i det tredje lag) eller bankunionen (så er det endnu mere uklart, hvem det andet lag består af). Det er endda muligt, at alle landene i det andet lag vil flytte til det første lag, så Storbritannien efterlades alene uden for eurozonen. Med andre ord er det også uklart, om det andet lag er stabilt.

De forskellige lande i det uklart definerede andet lag kæmper alle på forskellig måde med dilemmaet om, hvordan man beholder indflydelse i et EU, hvis tyngdepunkt har flyttet sig til eurozonen. I den ene ende af spektret af tilgange befinder Storbritannien sig. Det fjerner sig mere og mere fra eurozonen som led i en selvforstærkende (selv)marginaliseringsdynamik, der stammer fra før krisen, men som er accelereret, siden den startede: uenighed fører til 'opt-outs', som fører til manglende indflydelse, som fører til yderligere uenighed, som fører til yderligere 'opt-outs' og så videre. Denne dynamik har nu nået sin logiske slutning med den aktuelle debat om britisk medlemskab.

I den modsatte ende af spektret er Polen, som har valgt den næsten modsatte tilgang. Selv om landet ikke kan tilslutte sig euroen i øjeblikket på grund af den folkelige modstand, og måske ikke vil kunne gøre det foreløbigt, ser det politiske establisment det som sit langsigtede strategiske mål. Derfor er strategien at holde sig tæt til den nye 'kerne'. Det gør alt hvad der er muligt for at forpligte sig over for EU - fx ved at underskrive finanspagten, distancere sig fra Storbritannien og bidrage til europæisk udenrigspolitik. Imidlertid er Polen måske på en måde ved at starte den samme dynamik, som Storbritannien nu er ved at afslutte. Spørgsmålet er, hvor længe Polen kan undgå (selv)marginalisering uden at tilslutte sig den fælles valuta.

Lande som Tjekkiet, Danmark og Sverige, der i øjeblikket er i gråzonen mellem det andet og tredje lag kommer til at spille en afgørende rolle for EU's fremtid. Især Danmark, der er det eneste land bortset fra Storbritannien, som har en 'opt-out' med hensyn til ØMU'en, og derfor, i en forstand, det eneste andet land i det tredje lag. Britisk medlemskab af EU kan afhænge af det tredje lags anvendelighed. Hvis Storbritannien ikke er i stand til at etablere en meningsfuld rolle i denne position, vil det sandsynligvis forlade EU. Og det vil gøre det tredje lag mindre brugbart for andre lande. Det forandrede EU placerer således Danmark i en central position.

Oversat fra engelsk af Brita Vibeke Andersen.

Artiklen er en redigeret version af en tale, som Hans Kundnani holdt 31. marts 2014 på en EU-konference, arrangeret af bl.a. Det Udenrigspolitiske Selskab og Københavns Universitet. 